\title{
MONITORING POPULATIONS OF SAXIFRAGA CESPITOSA IN SCOTLAND
}

\author{
Kate Barnard ${ }^{l}$
}

\begin{abstract}
Saxifraga cespitosa is listed as Endangered on the UK Red List, compiled using IUCN criteria (Cheffings \& Farrell, 2005). It is also one of the species listed for conservation priority at the Royal Botanic Garden Edinburgh (RBGE) under Target 8 of the Global Strategy for Plant Conservation (GSPC). The species has been monitored extensively in the past, but there have been limited surveys in recent years. RBGE and the National Botanic Garden of Wales plan to survey all the UK locations of this species to increase information on existing populations and the threats to its survival. The field work and surveys carried out in 2013 are described in this paper and they have proved to be a useful learning experience for developing both staff skills and survey methods. Information on cultivation of the species from seed is also given. A field data sheet is provided as an appendix.
\end{abstract}

\section{DISTRIBUTION AND HABITAT OF SAXIFRAGA CESPITOSA}

Saxifraga cespitosa has a circumpolar distribution, ranging from Greenland to northern Siberia, Alaska and Arctic Canada (Webb, 1950). Within the UK it is restricted to seventeen sites, only one of which is outside Scotland, in Cwm Idwal, North Wales. In Scotland it occurs in mountainous areas which include the Grampian Mountains, the Ben Nevis to Ben Alder ranges, the Torridonian north-west Highlands and a recent record on the Trotternish Ridge on Skye. With the exception of records on Ben Eighe (which occurs at 760m) and Skye, all of the Scottish colonies occur above 1,000m (de Vere, 2013).

Saxifraga cespitosa is described as a pioneer species (Acock, 1940). In the Arctic regions it descends to sea level, and can be found in rock crevices, scree, gravel, stony tundra and shingle beaches (Webb \& Gornall, 1989). The UK populations are restricted by competition with other species to open, bryophyte-dominated communities of montane cliff ledges, boulders and scree (Webb, 1950). Constant erosion, harsh environmental conditions and late snow-lie limit the growth of higher plants that would create more competition (Parker, 1982; Webb, 1950). It grows on a variety of rock types from limestone to granite (Webb \& Gornall, 1989) and requires open drainage (Webb, 1950) (Fig. 1).

In cultivation, Saxifraga cespitosa is susceptible to winter dampness. Webb (1950)

1. Kate Barnard is a Horticulturist working in the Rock and Woodland Garden areas of the Royal Botanic Garden Edinburgh. Address: 20A, Inverleith Row, Edinburgh, EH3 5LR, UK.

Email: K.Barnard@rbge.org.uk 
suggests that to survive in natural habitats it requires either snow cover, a dry winter or shelter provided by overhanging ledges, and this should be replicated in cultivation.

MORPHOLOGY AND GROWTH PATTERN OF SAXIFRAGA CESPITOSA

The species is an evergreen perennial with short, rosette-like shoots which form a tufted appearance. The leaves are small, 4-15mm, with 3-5 lobes, and are covered in short glandular hairs (Webb, 1950; Webb \& Gornall, 1989). It has leafy shoots which form a tight cushion (Webb \& Gornall, 1989) although where shoot growth is longer and more straggling the form becomes less dense.

In spring the winter resting buds in the axils of lower leaves start to grow into short 'barren shoots'. Around midsummer, growth stops and the terminal bud of the barren shoot forms into a rosette. Winter buds develop in the leaf axils to provide the source of vegetative growth the following year. This is repeated annually to form a typical cushion plant (Webb, 1950).

A rosette is normally capable of producing a flowering stem the year after formation. When it does flower, the leaves wither away afterwards and the rosette dies (Webb, 1950). If the rosette does not flower, it persists to the following season, producing a fresh

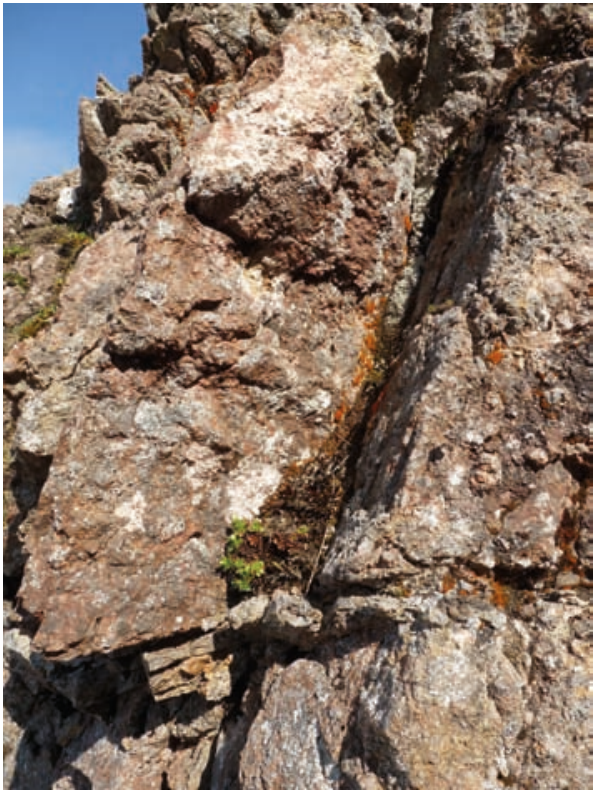

Fig. 1 Typical habitat and position occupied by Saxifraga cespitosa at Ben Avon. Photo: Kate Barnard.

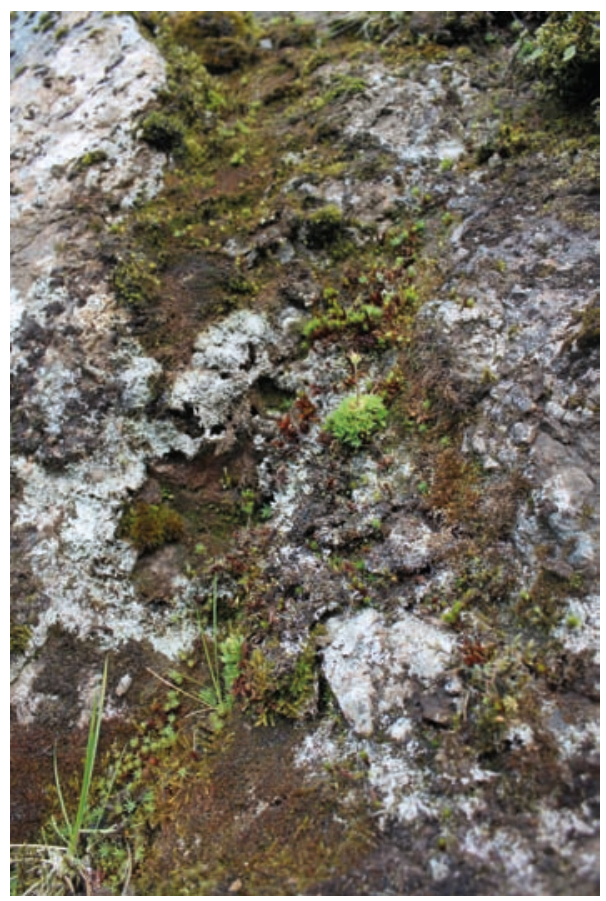

Fig. 2 Mature plant of Saxifraga cespitosa with immature seed head taken at Ben Alder. Photo: Natasha de Vere. 
whorl of leaves (Webb, 1950). The root system is adventitious, and in Spitzbergen it is described as a deep rooting plant (Acock, 1940).

Reproduction is mainly by seed, with flowers produced between June and August in the UK (Webb \& Gornall, 1989). The flowers are slightly protogynous, which means the stigma is receptive before the pollen is shed from the anthers on the same flower. The plants are also highly self-fertile, which makes self-pollination more likely to occur than cross-pollination (Parker, 1982). Seeds are dispersed by wind and heavy rainfall, and light is required for germination (Parker, 1982). This species was successfully germinated from Scottish origin seed at the Royal Botanic Garden Edinburgh (RBGE) in 2013. However it has proved more difficult to grow on from the seedling stage to a mature plant.

\section{THE SURVEY OF SAXIFRAGA CESPITOSA}

Target 8 of the Global Strategy for Plant Conservation (GSPC) states that at least 75 per cent of threatened species of a given country should be in an ex situ collection within that country by 2020 , with 20 per cent of those species available for potential recovery or restoration programmes. Emphasis should be placed on conserving a genetically representative sample of the population (Convention on Biological Diversity, 2012). Saxifraga cespitosa is on the list of species which RBGE has compiled and for which it has committed to operate conservation programmes as its contribution to Target 8 . As part of the conservation programme RBGE needed to increase knowledge of the natural habitat of the species, understand the threats to its survival and collect seed to increase the genetic base of the Living Collection.

The National Botanic Garden of Wales included this species as part of their Welsh Arctic Alpine project (de Vere, 2013). One aim of the project is to carry out research into the conservation genetics of the species in order to identify the relationship between the Welsh and Scottish populations. This information will be used to develop conservation management guidelines and inform strategies for future reintroduction programmes in Wales. The genetic data will also be used in the Barcode of Life Database (iBOL, 2014).

\section{LOGISTICS AND PLANNING}

\section{Data collection prior to field surveys}

Historic field records for Scottish populations were gained from the Botanical Society of the British Isles (BSBI) database. This provided a basis for planning the survey. Two areas were identified for survey by RBGE staff in 2013: Ben Avon and Ben Alder.

Detailed information for Ben Avon was taken from a Scottish Natural Heritage (SNH) survey of site condition monitoring of rare vascular plants, conducted in 2003 by Sandy Payne and Claire Geddes (Loizou, 2003). There were excellent site photos in this report which were invaluable in locating the site and identifying individual plants in 
2013. Unfortunately there was no similarly detailed survey covering the Ben Alder area, so individual field records were used.

\section{Status and legal protection}

S. cespitosa is a UK BAP species, on the Scottish Biodiversity List, and is listed as Endangered in the Red Data List for Great Britain (Cheffings \& Farrell, 2005). A licence was obtained from SNH, granted under the Wildlife and Countryside Act 1981 and the Conservation of Natural Habitats Regulations 1994. This gave permission to collect small amounts of leaf material for genetic analysis and seed, for the purposes of science, research and education.

\section{Permission for access}

Landowners were contacted in advance to arrange vehicle access on suitable dates that avoided stalking restrictions due to the shooting seasons. A 4WD vehicle was hired to enable efficient access to both these remote areas.

The site at Ben Avon was visited by two RBGE staff on 10 July 2013. A return visit was made on 29 September 2013, to collect seed. The multiple sites around Ben Alder were visited between 12 and 16 August 2013 by two RBGE staff and one member of staff from National Botanic Garden of Wales (NBGW).

This species survives in a remote mountain environment and due consideration of health and safety had to be made. This ranged from ensuring staff had suitable mountain skills such as competence in navigation, first aid and ropework, to providing and using climbing helmets, as loose rock was prevalent on many of the sites visited.

\section{DEVELOPMENT OF SURVEY METHODS}

\section{Ben Avon}

Photographs taken during the previous survey (Loizou, 2003) were used to identify the locations of the populations. As plants were located they were matched with the numbers given to the populations in 2003. This enabled a direct comparison to be made with the health of the plants ten years previously (Figs $1 \& 2$ ).

The same terms were used as in the SNH 2003 survey. A population referred to a discrete stand of $S$. cespitosa within the gully. Each population can be composed of one or more clumps, and each clump contains one or more rosettes. These are not standard ecological surveying methods, simply terms used in earlier surveys to describe the plants in this area.

The number of rosettes both alive and dead, old flowering spikes and the number of developing flower buds were counted. The clumps were measured and a rough sketch map of the populations was drawn, with the distance between each population measured. 
The following data were also recorded for each plant found: Ordnance Survey grid reference, altitude (m), accuracy of Global Positioning System (GPS) equipment reading $( \pm \mathrm{m})$, description of associated species and angle the plant was facing.

A single leaf was taken from the larger plants for DNA analysis. Each leaf collected was placed into a sealable plastic bag with silica gel and given a unique collection number.

On returning to this site in September, each population was marked temporarily with a yellow label, and the site was photographed, to show the location of each population.

\section{Ben Alder}

As there was no recent survey on the species in this area the survey methods differed from those used at Ben Avon. S. cespitosa has been recorded from eight sites in the Ben Alder area over the last forty years. Field records were grouped geographically and a number of sites were visited each day. Ordnance Survey maps and GPS were used to get to the correct grid reference for each location. A visual search was conducted using binoculars to scan the area and, where possible, by physically walking across the site.

As there was less information on the individual sites, each plant was numbered as a clump when found. After gaining experience at Ben Avon, field data sheets were constructed to record the raw information in the field (see Appendix 1). When plants were located they were temporarily marked with a yellow label and photographed. The steep terrain and changeable weather made it difficult to get good photographs of the overall site.

\section{SURVEY RESULTS}

\section{Results from Ben Avon}

Eight of the populations recorded in 2003 were no longer present. The number of separate populations had decreased by 63 per cent from eleven to four. The total number of separate clumps had decreased by 65 per cent from twenty to seven. The total number of rosettes had decreased by 55 per cent from 218 to 98 .

Within the three populations present in 2003 and 2013, a comparison of the rosettes shows no change in Population Seven, a 7 per cent decrease from 71 to 66 rosettes in Population Four and a 150 per cent increase from four rosettes to ten rosettes in Population Nine. These results are represented in the graphs shown in Figs 3 and 4. Material for DNA analysis was collected from four of the larger clumps.

The relative locations of the plants within the Ben Avon site are shown in Fig. 5. Unfortunately the accuracy of the GPS readings was poor, as the European Geostationary Navigation Overlay Service (EGNOS) correction signal was not received in the gully. However, once the general site was located on the hill, the plants are relatively easy to spot within the gully. 


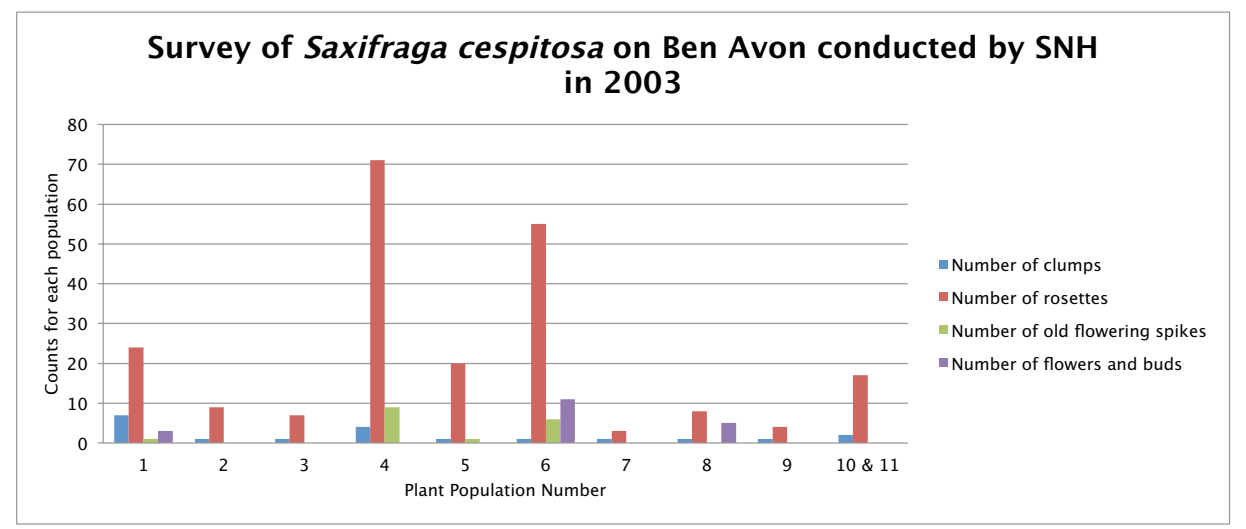

Fig. 3 Graph summarising results from the SNH survey in 2003.

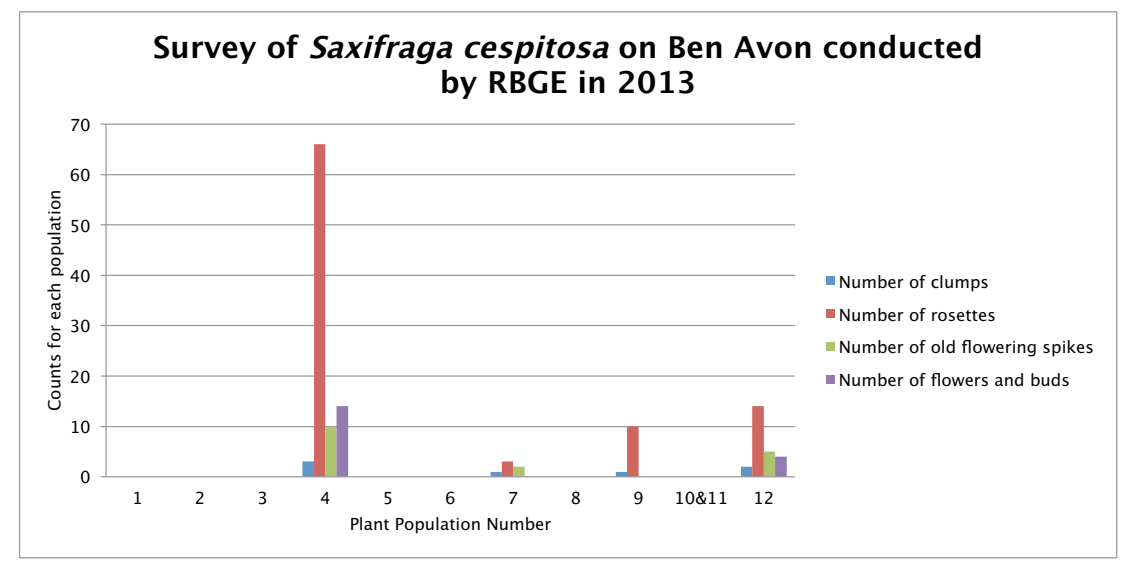

Fig. 4 Graph summarising the results from the RBGE survey in 2013.

The larger clumps all had developing flower buds (Fig. 6). The growth pattern of this species means that the rosette dies after flowering (Parker, 1982). This suggests that the surviving populations have maintained or slightly increased their rate of growth over the past ten years, to replace flowering rosettes that have died. The large decrease in the overall number of rosettes is due to the loss of individual populations, rather than a decline in the health of surviving populations.

\section{Results from Ben Alder}

S. cespitosa was only seen at one of the eight sites visited. Twenty clumps were found at this site, with a total of 119 living rosettes. Fig. 7 shows an example of one of the areas where plants were located. 


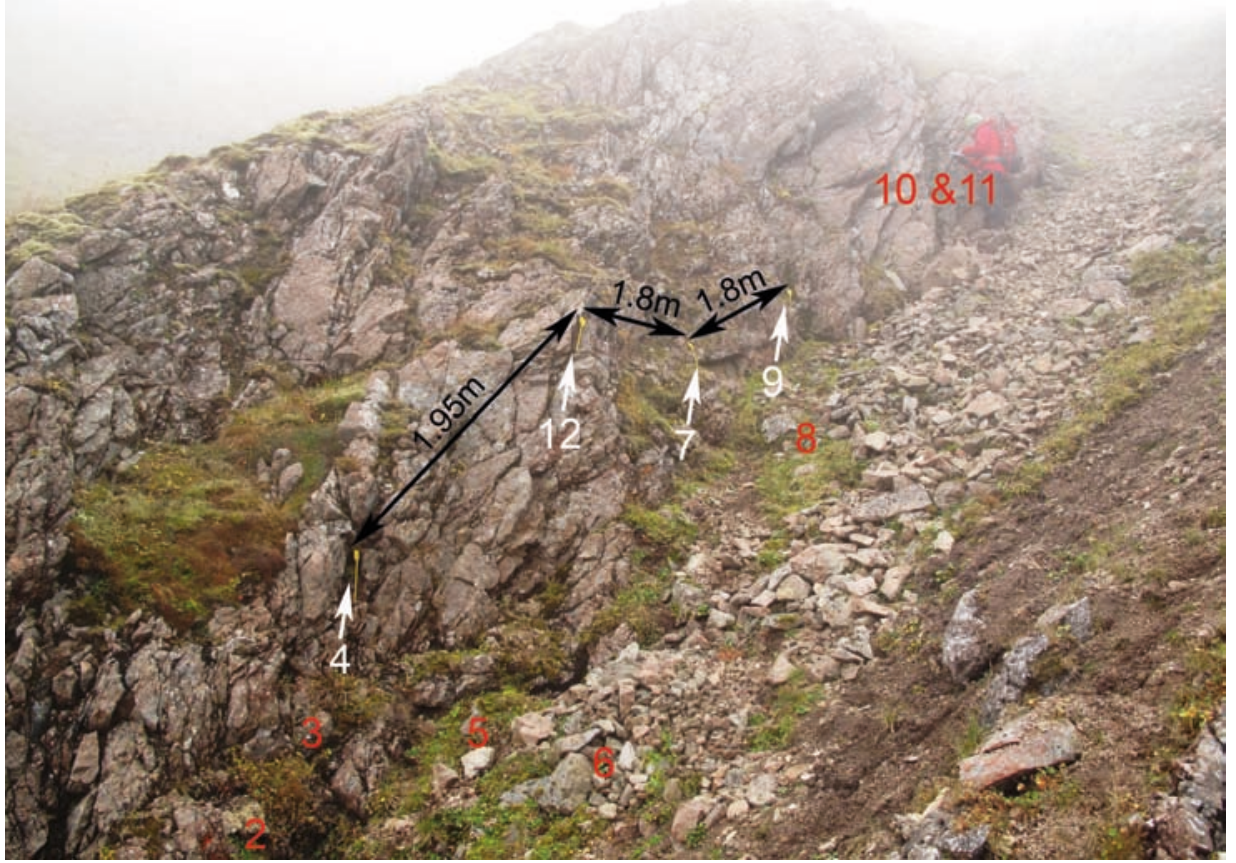

Fig. 5 Location of historic and existing populations on Ben Avon. Numbers in red indicate the location of populations recorded in 2003, but not present in 2013. Numbers in white show populations seen in 2003 and 2013. Distances between each population are indicated by the arrows. Photo: Simon White.

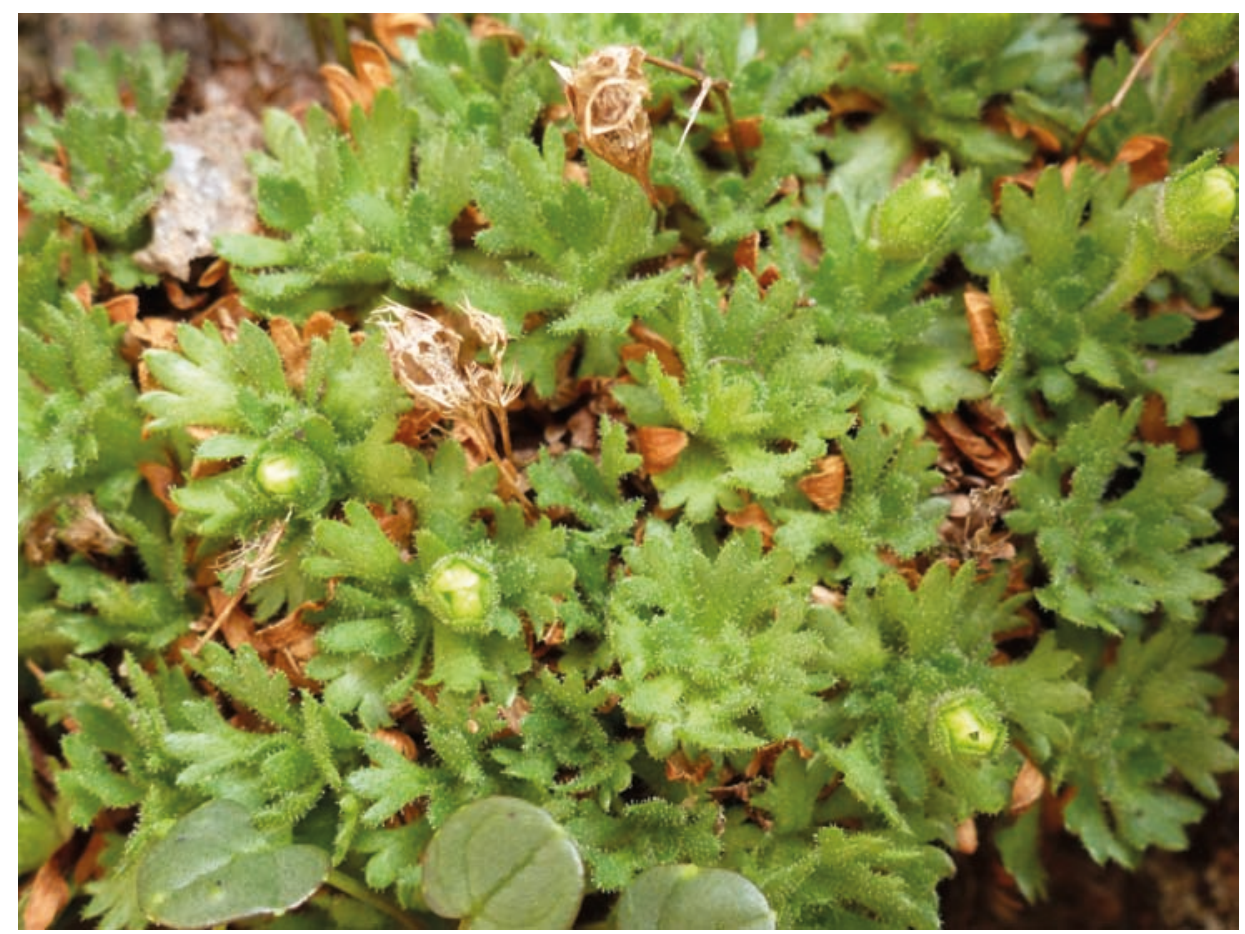

Fig. 6 Close up of developing flower buds and last year's seed heads. Photo: Paul Mullany. 
The number of living rosettes in each clump ranged from one to fifteen, with 55\% of the clumps having fewer than five living rosettes. These may have been counted as juveniles on previous field records. However, given the persistence of extremely small clumps on Ben Avon for ten years, it was decided to record everything as adult plants.

The physical size of the clumps varied from $10 \times 10 \mathrm{~mm}$ to $70 \times 55 \mathrm{~mm}$. One plant under an overhang appeared to have substantially larger leaves than any of the plants seen elsewhere. Twelve DNA samples were taken from the plants in this area.

In total over six hours was spent in this corrie over the course of two days. The terrain was very steep and often loose. Although we carried a rope and had equipment to be able to set up a belay, we did not do so, because the rock was extremely unstable. It is highly possible that there are other plants in this area that we failed to locate due to the nature of the terrain.

It would be a good idea to carry out future surveys during flowering season, which would help to pinpoint plants that might be growing on more inaccessible ledges. Unfortunately, on both days as we left the corrie the cloud descended, so there are no useful photos that show the locations of the plants set within the landscape.

Despite clear evidence of deer tracks on this site, and the fact that many of the plants were well within grazing height, there was no evidence of grazing, as many of the plants still had developing seed heads (Fig. 8).

It is not possible to draw the same conclusions as with the Ben Avon populations, because the historical field records are more variable. While it was a positive outcome to locate a number of healthy plants in one location and obtain DNA samples, it was disappointing not to find the plant in the many other historical locations in the Ben Alder area.

\section{SAXIFRAGA CESPITOSA FROM SEED AND IN CULTIVATION}

Seed was collected under licence by Marion Moir, a volunteer for the Scottish Plants Project which was running at that time, from one plant on the Ben Nevis site in October 2012. An initial sowing was made in November 2012 in a mix of three parts John Innes seed to one part chick grit. The pot was top-dressed with chick grit and placed in a north-facing cold frame. A repeat sowing was made in May 2013 under the same conditions.

Germination was observed in the first sowing in May 2013 (three seedlings), and in the second sowing in July 2013 (five seedlings). In August 2013, all seedlings were pricked out into $9 \mathrm{~cm}$ plastic pots in Standard Alpine Mix. Standard Alpine Mix comprises one part John Innes No. 2, one part flint hen grit (max diameter 3mm) and one part sieved leaf mould. These were placed outside over the summer and moved into an unheated polytunnel over winter.

Five seedlings died in the winter; the most likely cause was that the pots were too large for the small plants, leading to rotting off due to waterlogging. Once growth commenced in late spring 2014, the remaining plants were repotted into smaller $6 \mathrm{~cm}$ diameter plastic pots and placed into an unheated, well-ventilated greenhouse. 


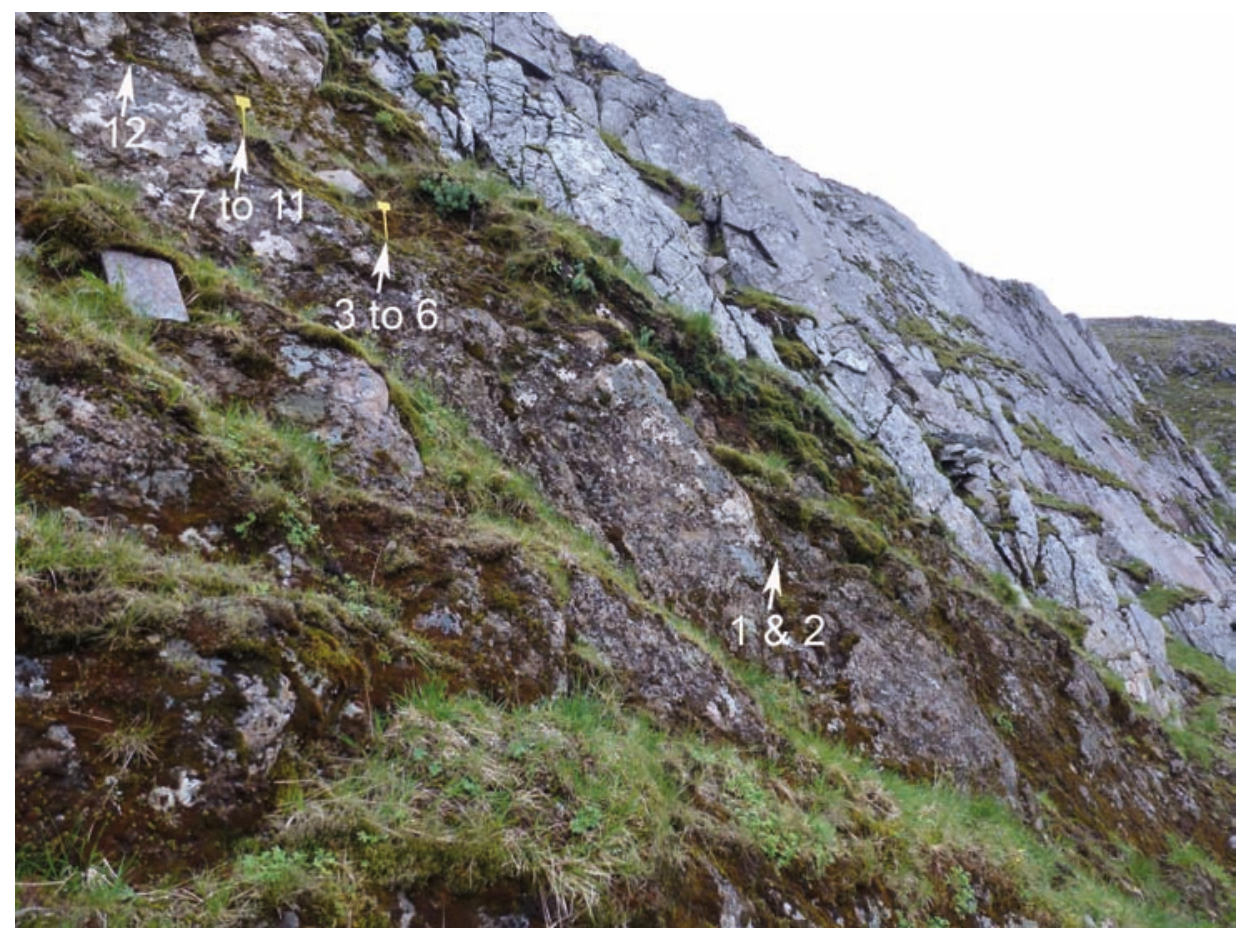

Fig. 7 Saxifraga cespitosa in Coire na Coichille, clumps 1 to 12. Photo: Paul Mullany.

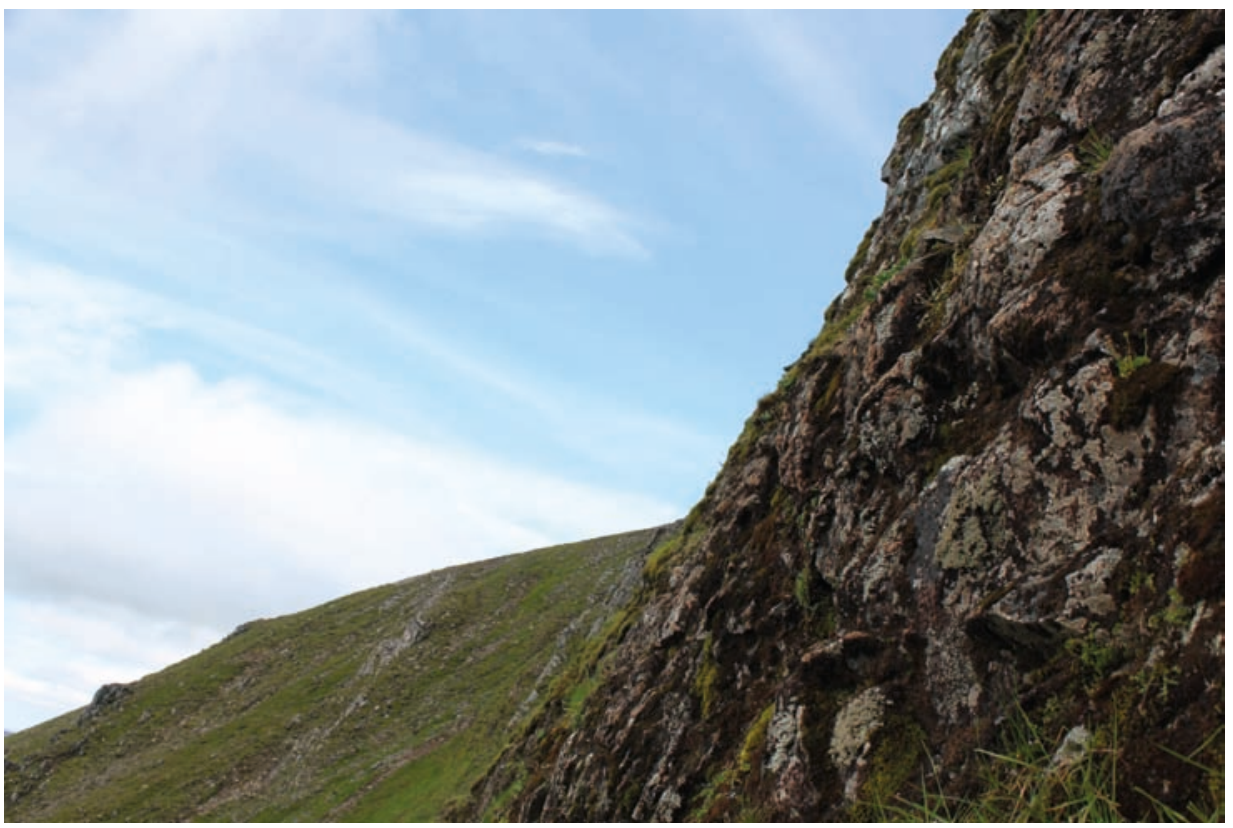

Fig. 8 Solitary clump of Saxifraga cespitosa with developing seed heads at Ben Alder on the extreme centre right of the photo. Photo: Natasha de Vere. 
The remaining plant from the first sowing now has three rosettes (Fig. 9), and the other two plants have one and two smaller rosettes.

For optimum results when propagating from seed it appears to be best to wait for a complete growing season before pricking out. Seedlings will then have developed a small rosette, with a better root system. Protection from frost and excessive rainfall over winter is also advisable. To ensure the long-term survival of the species in cultivation it would be sensible to take cuttings before the rosettes get to flowering size, as individual rosettes die after flowering.

The seed germinated remarkably quickly and did not appear to require a period of chilling in the pot, although the seed for the second sowing had been stored in the fridge prior to sowing. The remaining seed from the initial collection and two further seed collections have now

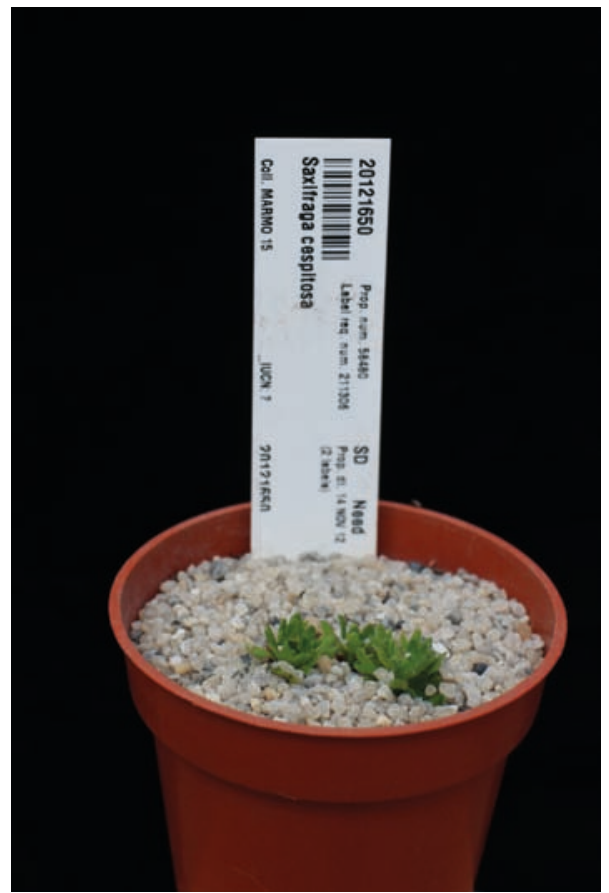

Fig. 9 Saxifraga cespitosa plant from the first sowing in May 2013. Photo: Robert Unwin. been dried and are being stored at $-20^{\circ} \mathrm{C}$.

Although germination was quick, the seedlings are slow to develop rosettes and need to be treated with care.

Once sufficient mature plants are obtained for the ex situ collection, they will be planted into public display areas at RBGE. Due to their small size and requirement for free draining soil they will be best suited to the troughs located in the Alpine display area which are dedicated to the display of Scottish native species.

\section{LEARNING OPPORTUNITIES AND CONCLUSIONS}

There is still field work visiting all the sites to complete in 2014, therefore it is difficult to comment on the overall health of this species in Scotland. However, valuable experience has already been gained from this work and this is discussed below.

In the process of writing up the results of the surveys the issue of data storage and dissemination of our findings was raised. It would be useful to have a standardised reporting format used by all conservation organisations to allow results to be easily compared. There is also potential for a more collaborative approach to threatened plant monitoring between organisations involved in plant conservation within the UK.

Time spent assessing and summarising historical site records was important in order to gather meaningful data, and this allowed effective use of limited time in the 
field. In addition to close-up photographs of individual plants, clear photos of the larger landscape, which show the approach and identification of site locations, are a valuable tool for future surveys.

An understanding of the lifecycle and growth pattern of the species being studied is essential to determine which characteristics are important and therefore what information to record. The field data card proved to be an efficient way of recording data in the field and can be used for long-term monitoring to allow comparison over time.

Although this piece of work involved more botanical skills than are often employed by horticulturists, it really helped to see the type of habitat occupied by this threatened species in Scotland both to carry out the survey and cultivate it successfully at RBGE. We quickly developed an 'eye' for the sites where we were more likely to see the species, and gained valuable field experience and practical field botany skills from the project. These skills and enthusiasm can be transferred to working with the ex situ collections of native species at RBGE.

\section{ACKNOWLEDGEMENTS}

Thanks to the people who provided advice and support organising and carrying out this field work: Richard Marriot, Heather McHaffie, Iain Macdonald, Paul Mullany and Natasha de Vere.

\section{REFERENCES}

ACOCK, A.M. (1940). Vegetation of a calcareous inner fjord region in Spitsbergen. Journal of Ecology 28(1): 81-106.

CHEFFINGS, C. \& FARRELL, L. (eds) (2005). The Vascular Plant Red Data List for Great Britain. JNCC, Peterborough.

CONVENTION ON BIOLOGICAL DIVERSITY (2012). Global Strategy for Plant Conservation: 2011-2020. Botanic Gardens Conservation International, Richmond. Available at: http://www.cbd.int/gspc/strategy.shtml (Accessed: 1 June 2014).

DE VERE, N. (2013). Welsh Arctic Alpines NRW Final Report. National Botanic Garden Wales, Llanarthne.

iBOL (2014). Barcode of Life. Available at: http://www.barcodeoflife.org/ (Accessed: 25 June 2014).

LOIZOU, T. (2003). Site Condition Monitoring of Rare Vascular Plants. Report for Scottish Natural Heritage.

PARKER, D. (1982). Studies on the dactyloid saxifrages (Saxifraga L. Section Dactyloides Tausch) of the British Isles. PhD thesis, University of Liverpool.

WEBB, D.A. (1950). Biological flora of the British Isles. Saxifraga L. (section Dactyloides Tausch). Journal of Ecology 38: 185-213.

WEBB, D.A. \& GORNALL, R.J. (1989) Saxifrages of Europe. Christopher Helm, London. 


\section{APPENDIX 1: FIELD DATA FOR SAXIFRAGA CESPITOSA IN COIRE NA COICHILLE}

Date: 13 August 2013

Initials of surveyors: $\mathrm{KB}, \mathrm{PM}, \mathrm{NV}$

Grid reference for centre of site: NN4693 7461

Altitude: $1,084 \mathrm{~m}$

Accuracy: $3 \mathrm{~m}$

Euro Geostationary Navigation Overlay Service on: NO

\begin{tabular}{|c|c|c|c|c|c|c|c|c|c|c|c|c|c|}
\hline Clump no. & 1 & 2 & 3 & 4 & 5 & 6 & 7 & 8 & 9 & 10 & 11 & 12 & 13 \\
\hline $\begin{array}{l}\text { No. living } \\
\text { rosettes }\end{array}$ & 12 & 14 & 1 & 1 & 1 & 1 & 2 & 2 & 3 & 2 & 4 & 13 & 6 \\
\hline $\begin{array}{l}\text { No. dead } \\
\text { rosettes }\end{array}$ & 0 & 0 & 0 & 0 & 0 & 0 & 0 & 0 & 0 & 0 & 0 & 0 & 0 \\
\hline $\begin{array}{l}\text { No. } \\
\text { flowers/ } \\
\text { buds }\end{array}$ & 1 & 0 & 0 & 0 & 0 & 0 & 2 & 1 & 2 & $\begin{array}{l}2 \\
\text { stalks } \\
3 \\
\text { flowers }\end{array}$ & 0 & $\begin{array}{l}5 \text { stalks } \\
6 \\
\text { flowers }\end{array}$ & $\begin{array}{l}6 \\
\text { stalks } 4 \\
\text { flowers }\end{array}$ \\
\hline $\begin{array}{l}\text { No. } \\
\text { dehisced } \\
\text { spikes }\end{array}$ & 1 & 0 & 0 & 0 & 0 & 0 & 0 & 0 & 0 & 0 & 0 & $\begin{array}{l}4 \text { stalks } \\
5 \\
\text { flowers }\end{array}$ & 0 \\
\hline $\begin{array}{l}\text { Size of } \\
\text { clump } \\
(\mathrm{mm})\end{array}$ & $35 \times 40$ & $\begin{array}{l}60 \times \\
40\end{array}$ & $\begin{array}{c}10 \\
\times \\
10\end{array}$ & $\begin{array}{c}10 \\
\times \\
10\end{array}$ & $\begin{array}{c}10 \\
\times \\
10\end{array}$ & $\begin{array}{c}10 \\
\times \\
10\end{array}$ & $\begin{array}{l}10 \times \\
20\end{array}$ & $\begin{array}{l}14 \times \\
20\end{array}$ & $\begin{array}{l}15 \times \\
25\end{array}$ & $\begin{array}{l}20 \times \\
10\end{array}$ & $\begin{array}{c}25 \\
\times \\
15\end{array}$ & $\begin{array}{l}38 \times \\
47\end{array}$ & $55 \times 36$ \\
\hline $\begin{array}{l}\text { Distance } \\
\text { and } \\
\text { direction to } \\
\text { next clump }\end{array}$ & $\begin{array}{l}11 \mathrm{~cm} \text { up } \\
\text { slab to } \\
\text { clump } 2\end{array}$ & $\begin{array}{l}4 \mathrm{~m} \\
\text { up } \\
\text { slab } \\
\text { to } \\
\text { clump } \\
12\end{array}$ & $\begin{array}{l}\text { even } \\
\text { apar }\end{array}$ & & ed $5 c$ & & $\begin{array}{l}9.5 \mathrm{~cm} \\
\text { from } \\
\text { clump } \\
6\end{array}$ & $\begin{array}{l}17.5 \\
\mathrm{~cm} \\
\text { from } \\
\text { clump } \\
7\end{array}$ & $\begin{array}{l}25 \mathrm{~cm} \\
\text { from } \\
\text { clump } \\
8\end{array}$ & $\begin{array}{l}2 \mathrm{~cm} \\
\text { from } \\
\text { clump } \\
9\end{array}$ & & $\begin{array}{l}1 \mathrm{~m} \text { up } \\
\text { slab to } \\
\text { clump } \\
13\end{array}$ & \\
\hline $\begin{array}{l}\text { DNA } \\
\text { sample } \\
\text { number }\end{array}$ & 7 & 8 & & & & & & 12 & 11 & & & 9 & 10 \\
\hline $\begin{array}{l}\text { Angle plant } \\
\text { facing }\end{array}$ & $288^{\circ}$ & $353^{\circ}$ & & & & & & & & & & $323^{\circ}$ & $\begin{array}{l}\text { not } \\
\text { recorded }\end{array}$ \\
\hline $\begin{array}{l}\text { Associated } \\
\text { sp. }\end{array}$ & \multicolumn{13}{|c|}{$\begin{array}{l}\text { No directly associated species apart from Racomitrium lanuginosum, Rhodiola rosea, Oxyria digyna, Salix } \\
\text { herbacea were all in the vicinity. }\end{array}$} \\
\hline $\begin{array}{l}\text { Description } \\
\text { of area }\end{array}$ & \multicolumn{13}{|c|}{$\begin{array}{l}70^{\circ} \text { rock slab, brown friable rock, facing } \mathrm{N}\left(323^{\circ}\right) \text {. Plants on small ledges on rock. Clump } 13 \text { was under a } \\
\text { slight overhang and had much larger rosettes compared to the other clumps on this site. Photos for this site } \\
\text { taken from NN } 4693374622,1,081 \mathrm{~m} \text {. Clumps described from bottom of the slab to the top. The small clumps } \\
\text { numbered } 3 \text { to } 11 \text { were roughly in the middle of the slab. They were spotted after the four larger clumps } \\
\text { above and below them had already been recorded. }\end{array}$} \\
\hline
\end{tabular}

